\title{
Evaluation of Topographical Co-Cr-Mo Alloy Surface Changes After Various Finishing Treatments
}

\section{Procjena topografskih promjena površine Co-Cr-Mo legure poslije različitih završnih postupaka obrade}

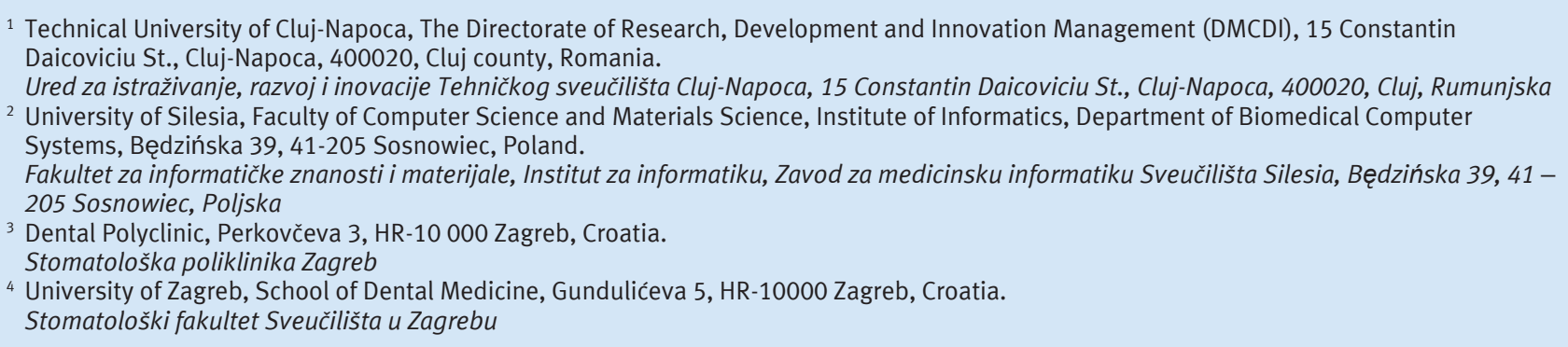

Abstract

Purpose: To quantify the influence of three different finishing treatments on the cobalt-chromiummolybdenum (Co-Cr-Mo) alloy surface based on stereometric analysis parameters. Materials and methods: Eighteen specimens were casted from an extra-hard alloy (Wironit ${ }^{\circledR}, \mathrm{BEGO}$, Bremen, Germany). The samples were distributed into three groups ( $n=6$ samples per group) dependent on different polishing techniques applied, as follows: A group, only electropolished (EP) samples; B group, after EP, an additional mechanical polishing process was applied to the surface by rubber discs and a polishing paste (RP); C group, after EP, an additional mechanical polishing process was completed by rubber discs, polishing paste and finally by a rotating deer leather wheel (RPDL). Samples were imaged by atomic force microscopy (AFM) in a contact mode, in air, at room temperature. Results: The evaluation of the microtexture of the sample surface was made based on the 3-D roughness parameters. The lowest statistical surface roughness parameters were found in the RP samples, whereas the highest values were obtained from the EP samples. Conclusions: The experiments described can help manufacturers identify the most appropriate parameters and their ranges within which optimal surface characteristics can be achieved.
Received: October 31, 2018

Accepted: April 2019

Address for correspondence Professor Asja Čelebić University of Zagreb

School of Dental Medicine Department of removable prosthodontic

Gundulićeva 5, 10000 Zagreb, Croatia celebic@sfzg.hr

Key words

Dental Polishing; Dental Alloys; Cobalt; Chromium; Molybden; Surface Properties

\section{Introduction}

In the last few decades, cobalt-chromium-molybdenum (Co-Cr-Mo) alloys have shown high mechanical features and resistance to wear and corrosion when used as orthopedic implant materials or in other biomedical applications. These alloys belong to a group of the hardest known alloys with biocompatible characteristics. They also possess some other good properties such as tensile strength, fatigue resistance, as well as good corrosion resistance. Co-Cr-Mo alloys are now commonly used as implants in artificial hip and knee joints, and in the manufacturing of metal frameworks for removable dentures in order to prevent fractures. In advanced biomaterials studies, most of them deal with biological response mechanisms to carry residues (metal particles or metal oxide particles, etc.) and oxidation products (cations, metal oxides, metal phosphates, etc.).

\section{Uvod}

Posljednjih desetljeća pokazalo se da kobalt-krom-molibdenove (Co-Cr-Mo) legure imaju dobra mehanička svojstva te otpor na koroziju i trošenje, pa su zato u uporabi kao materijali za implantate u ortopediji ili biomedicini. Istaknimo da se ubrajaju među najtvrđe biokompatibilne legure. $U$ druga dobra svojstva ubrajaju se snaga pri istezanju (tensile strength), otpornost na zamor i dobra otpornost na koroziju. Co-Cr-Mo legure obično se upotrebljavaju kao implantati za umjetne zglobove kuka ili koljena te za izradu metalnih skeleta mobilnih zubnih proteza zbog prevencije njihova loma. Većina naprednih studija o biomaterijalima bavi se mehanizmima biološkog odgovora na zaostatke (čestice metala ili čestice metalnog oksida itd.) i produkte oksidacije (kationi, metalni oksidi, metalni fosfati itd.). 
In contemporary dentistry, Cobalt-Chromium $(\mathrm{Co}-\mathrm{Cr})$ dental alloys have been utilized lately in applications which require highly biocompatible, wear resistance, corrosion resistance and/or thermal resistance features (1-6). Removable partial dentures (RPDs) have been manufactured mostly of this alloy, although the alloy can also be utilized for fixed partial dentures. Traditional fabrication technique for $\mathrm{Co}-\mathrm{Cr}$ Mo alloy is casting.

Additive manufacturing (AM) technology leads to exciting new developments in the field of medical implant manufacturing. Selective laser melting (SLM) is an additive cutting edge technology that can be applied in the production of complex metal parts, as well as for the manufacture of complete or partial removable and fixed prostheses. The realization of materials with advanced properties can be achieved by the SLM casting process which is essentially based on the rapid melting and rapid solidification of the metal powder (7). A high-energy laser beam acts on the metal powder as a heat source and causes rapid melting, followed by rapid solidification over a short period of time. The rate of melting and solidification depend on the energy density of the laser. However, SLM produced alloys need additional research in terms of long-lasting biocompatibility and technical precision. Due to a lack of long lasting evidence and high price of new technologies, most of dental laboratories worldwide still use traditional procedures for metal framework production such as casting.

Surface characteristics of a dental alloy are in direct correlation with the area of the contact surface. These characteristics influence its biocompatibility, its corrosion, and microorganism and/or how it interacts with human cells (8).

Some studies found out a correlation between the high value of parameters of surface roughness of materials in the oral cavity and increased incidence of oral infectious diseases, such as dental caries, gingivitis, periodontal disease, and inflammation of the oral mucosa (9-12). Mechanical techniques that smoothed surfaces for application in the oral cavity showed positive influence on both, oral health and resistance to corrosion of an alloy, moreover, bacterial adhesion and colonization was decreased (13).

Several researchers highlighted that surfaces of $\mathrm{Co}-\mathrm{Cr}$ dental alloys appear in a form of typical dendritic microstructure after solidification. Under a light microscope the surface of the alloy showed dark regions which were alternating with light regions $(14,15)$.

The evaluation of surface micromorphology of Co-CrMo dental alloy with AFM studies (16), in correlation with the manufacturing process (17), has been made in recent years (18-20). On the other hand, some investigators applied modern mathematical tools (21-26) for the 3-D microtexture description of various dental materials (27-31).

In this study, the surface microtexure of the Co-Cr-Mo dental alloy subjected to different sequences of electropolishing and further mechanical polishing procedures was studied, using AFM stereometric analysis.
U suvremenoj stomatologiji, kobalt-kromove (Co-Cr) legure često se primjenjuju ako su potrebni iznimno biokompatibilni uvjeti, otpornost na habanje te korozijska i/ ili toplinska otpornost $(1-6)$. Djelomične mobilne proteze (RPD-s) najčšśce se izrađuju od te legure, premda se ona upotrebljava i za izradu fiksnih protetičkih radova. Tradicionalni način izrade objekata iz Co-Cr-Mo legure jest lijevanje.

Tehnologija aditivne proizvodnje (AM-a) rezultira uzbudljivim novijim postignućima u području izrade medicinskih implantata. Selektivno lasersko taljenje (SLM) smatra se vrhunskom aditivnom tehnologijom koja se može primijeniti u proizvodnji složenih metalnih dijelova te za izradu potpunih ili djelomičnih mobilnih i fiksnih protetičkih radova. Izrada materijala naprednih svojstava može se postići postupkom selektivnog laserskog taljenja (SLM-a) koji se u osnovi temelji na brzom taljenju i brzom stvrdnjavanju metalnoga praha (7). Visoko energijska laserska zraka djeluje na metalni prah kao izvor topline i uzrokuje njegovo brzo otapanje, nakon čega slijedi brzo stvrdnjavanje u kratkom vremenu. Brzina taljenja i stvrdnjavanja ovise o energijskim obilježjima (gustoći) lasera. No za legure proizvedene postupkom selektivnoga laserskog taljenja potrebna su dodatna klinička istraživanja $\mathrm{u}$ vezi s dugotrajnom biokompatibilnošću i tehničkom preciznošću. Upravo zbog nedostatka dugotrajnih dokaza i visoke cijene tih tehnologija, većina stomatoloških laboratorija diljem svijeta i dalje se koristi tradicionalnim postupcima za proizvodnju metalnih radova, poput lijevanja. Površinske značajke dentalnih legura u izravnoj su korelaciji s izgledom i veličinom kontaktne površine. One utječu na biokompatibilnost, koroziju i mikroorganizame i/ili na način interakcije s ljudskim stanicama (8).

Autori nekih studija otkrili su povezanost između visokih vrijednosti parametara površinske hrapavosti materijala u usnoj šupljini i povećane učestalosti oralnih infektivnih bolesti, poput zubnog karijesa, gingivitisa, parodontne bolesti i upale oralne sluznice $(9-12)$. Tehnike mehaničkog izglađivanja površina koje se unose u usnu šupljinu pokazale su pozitivan utjecaj na oralno zdravlje i na otpornost prema koroziji legure, a adhezija i kolonizacija bakterija bila je smanjena (13). U nekoliko istraživanja navodi se da se površine Co$\mathrm{Cr}$ dentalnih legura nakon stvrdnjavanja pojavljuju u obliku tipične dendritične mikrostrukture. Pod svjetlosnim mikroskopom na površini legure uočavaju se tamna područja koja se izmjenjuju sa svijetlim regijama $(14,15)$. U posljednjih nekoliko godina u AFM studijama otkriveno je da je površinska mikromorfologija Co-Cr-Mo legure (16) u korelaciji s proizvodnim postupkom (17) $(18-20)$. Neki su istraživači također primijenili moderne matematičke alate $(21-26)$ za trodimenzionalni opis raznih stomatoloških materijala (27 -31 ).

U ovom istraživanju pomoću AFM stereometrijske analize proučena je površinska mikroteksture Co-Cr-Mo dentalne legure nakon različitih završnih obrada (elektropoliranja i daljnjih postupaka mehaničkog poliranja). 


\section{Materials and methods}

\section{Samples}

A commercial Co-Cr-Mo alloy (Wironit ${ }^{\circledR}$ extra-hard, Bego, Germany, $63 \%$ Co, $30 \%$ Cr, $5 \% \mathrm{Mo}$, and Si, Mn and $\mathrm{C}<2 \%$ ) was used for sample preparations. A total of 18 casted samples were made and finally polished in three different ways. Square wax samples $8 \times 8 \times 2 \mathrm{~mm}$ were made from wax (Modelling wax standard, DeguDent GmbH, Germany) and were invested into the investment material (Castorit super C; Dentaurum, Ispringen, Germany) as recommended by the manufacturer.

We preheated the wax samples at a recommended temperature $(1273 \mathrm{~K})$ and then we casted them with a vacuum casting machine (Nautilus, Bego, Germany) at a recommended temperature (1693 K), according to the manufacturer recommendations. After casting and cooling, we cleaned off the investment material particles in a sandblasting machine (Austenal Dentastrahl VE2, Germany) with particles of aluminum oxide $(250 \mu \mathrm{m})$, until all residues of the investment material were removed.

\section{Final surface treatments}

Sandblasting and a 15-minute electro polishing were applied to all samples (Eltropol SL electropolishing machine, Bego, Germany). Megalyt Megadental GmbH, Germany was the electrolyte polishing solution. Subsequently, those specimens were distributed into groups A, B and C (each one consisting of six specimens).

The A group comprised 6 electropolished specimens (EP) without any further manufacturing.

The B group (RP), comprised six electropolished samples, which were additionally polished mechanically by a rotating rubber disk polisher (Fine-grit, Dentaurum, Ispringen, Germany) and finally finished using a polishing paste for a high shine (Sherapol 705, Shera GmbH, Germany) and a rotating polishing brush.

The $\mathrm{C}$ group, (six RPDL samples), was first electropolished and, further polished mechanically with a rotating rubber disk (Fine-grit, Dentaurum, Ispringen, Germany) and a polishing paste (Sherapol 705, Shera GmbH, Germany). Finally, the RPDL sample polishing was completed with a 70$\mathrm{mm}$ radius deer-leather rotating polishing wheel (Dlesk, Zagreb, Croatia). The deer leather polishing wheel and the paste were used for three minutes.

The mechanical polishing procedures (after the electropolishing procedure) in the group two and the group three were done under light pressure by one experienced dental technician. The dental technician tried to equalize the pressure of specimens as much as possible against the rotating polisher.

\section{Sample cleaning}

To be ready for the AFM analysis, specimens were thoroughly cleaned. The following procedures were performed on all samples: cleaning with alcohol; rinsing in ultrapure water; sonicating for a period of $10 \mathrm{~min}$ in ultrapure water; drying with absorbent paper.

\section{Materijal i metode}

Uzorci

Za pripremu uzoraka korištena je komercijalna $\mathrm{Co}-\mathrm{Cr}$ Mo legura (Wironit ekstra tvrda, Bego, Njemačka - $63 \%$ Co, $30 \%$ Cr, $5 \% \mathrm{Mo}$, a Si, Mn i C < $2 \%$ ). Ukupno je pripremljeno 18 lijevanih uzoraka, a završno poliranje obavljeno je na tri različita načina. Uzorci su izliveni. Kvadratići voska 8 × 8 × $2 \mathrm{~mm}$ (vosak za modeliranje, DeguDent GmbH, Njemačka) stavljeni su u uložni materijal (Castorit super C; Dentaurum, Ispringen, Njemačka) prema preporuci proizvođača. Prije lijevanja uzorci voska u uložnom materijalu zagrijani su na preporučenoj temperaturi (1273 K) (predgrijavanje), a zatim su izliveni u uređaju za vakuumsko lijevanje (Nautilus, Bego, Njemačka) na temperaturi (1693 K) prema preporukama proizvođača. Nakon lijevanja i hlađenja uzorci su očišćeni od ostataka mase za ulaganje u uređaju za pjeskarenje (Austenal Dentastrahl VE2, Njemačka) s pomoću čestica aluminijskih oksida $(250 \mu \mathrm{m})$. Pjeskareni su sve dok nisu uklonjeni svi ostatci uložnog materijala.

\section{Završni postupci obrade površine}

Svi uzorci su pjeskareni i nakon toga elektropolirani 15 minuta (Eltropol SL elektropoliranje, Bego, Njemačka). Megalyt Megadental (GmbH, Njemačka) korišten je kao elektrolitska otopina za poliranje. Nakon toga uzorci su raspoređeni u skupine A, B i C (svaka je sadržavala po šest uzoraka).

U A skupini bilo je šest elektropoliranih uzoraka (EP-a) kojima je to istodobno bila i završna obrada.

Skupinu B (RP) činilo je šest elektropoliranih uzoraka koji su još dodatno mehanički polirani rotirajućim gumenim diskovima (Fine-grit, Dentaurum, Ispringen, Njemačka) i na kraju pastom za poliranje visokoga sjaja (Sherapol 705, Shera $\mathrm{GmbH}$, Njemačka) i rotirajućom četkom za poliranje.

Uzorci u C skupini (šest uzoraka RPDL-a) najprije su elektropolirani i zatim mehanički polirani gumenim rotirajućim diskom (Fine-grit, Dentaurum, Ispringen, Njemačka) i pastom za poliranje (Sherapol 705, Shera GmbH, Njemačka). Konačno poliranje uzorka RPDL-a završeno je rotirajućim kotačem za poliranje s jelenjom kožom promjera $70 \mathrm{~mm}$ (Dlesk, Zagreb, Hrvatska). Poliranje rotirajućom četkom ili jelenjom kožom i pastom za poliranje trajalo je tri minute. Mehaničke postupke poliranja (nakon postupka elektropoliranja) u drugoj i trećoj skupini obavio je, laganim pritiskom, iskusan zubni tehničar koji je pokušao izjednačiti pritisak pri poliranju uzoraka koliko god je to bilo moguće.

\section{Čišćenje uzoraka}

Kako bi uzorci bili spremni za AFM analizu, temeljito su očišćeni najprije alkoholom, zatim su ispirani u ultračistoj vodi, tretirani ultrazvukom u ultračistoj vodi (sonificiranje 10 min.) i osušeni upijajućim papirom. 


\section{AFM analysis}

We obtained AFM micrographs $(100 \mu \mathrm{m} \times 100 \mu \mathrm{m})$ of the specimens at constant temperature, air humidity, in air, in a contact mode, by the Multimode AFM, and the Nanoscope IIIa controller. Surface regions of interest (ROIs) were identified by an optical camera (Sony high resolution CCD camera, Japan). A more detailed description of the AFM measurements can be found elsewhere (18-20).

\section{3-D surface roughness statistical description}

MountainsMap Premium software version 7 was applied to extract information about the 3-D surface microtexture (32). These parameters of 3-D surface microtexture are described in ISO 25178-2:2012 (33).

The computation of Minkowski functionals (MFs) (volume $V$, surface $S$ and Euler-Poincaré characteristics (or connectivity number $\chi$ )) was made with Gwyddion 2.37 software (34) based on the following mathematical formulas:

$V=N_{\text {white }} / N ; S=N_{\text {bound }} / N ; \chi=\left(C_{\text {white }}-C_{\text {black }}\right) / N(1)$

where: $N$ is the total number of pixels; $N_{\text {white }}$ is the number of 'white' pixels, which are pixels above the threshold; $N_{b o}$ is the number of white-black pixel boundaries; and $C_{\text {white }}$ bond $C_{\text {black }}$ are the number of continuous sets of white and black pixels, respectively.

\section{Statistical analysis}

Statistical Package for the Social Sciences (SPSS, version 20, Illinois, USA) was used to analyze statistics. Quantitative variables between different groups were compared by one-way analysis of variance (ANOVA), and Post hoc test by the Scheffé test. The level of significance was considered significant for $p<0.05$.

\section{Results}

The relevant 2-D AFM images of samples, for a $100 \mathrm{x}$ $100-\mu \mathrm{m}^{2}$ scanning square area, are shown in Figure 1, for all three groups.

Figure 2 also shows a set of $S k$ parameters. Parameter $S k$ provides information on the depth of the core and can be determined using a line that intersects the $X$-axis on $0 \%$ and $100 \%$. On the graphical representation, two lines parallel to the $X$-axis are drawn and the computed values of parameter $S k$ for each group are: a) $S k=0.17 \mu \mathrm{m}$; b) $S k=0.201 \mu \mathrm{m}$; c) $S k=0.183 \mu \mathrm{m}$.

To graphically determine the values of the parameters, Smr1 and Smr2 are drawn parallel lines with the $Y$-axis, which will intersect with the parallel lines with the $X$-axis, previously drawn in the calculation of the parameter $S k$. The computed values of $\operatorname{Smr} 1$ parameter are: a) $13.8 \%$, (Figure 2a), b) $11.8 \%$, (Figure 2b); c) $11.7 \%$, (Figure 2c), while for Smr 2 parameters are: a) $88.6 \%$, (Figure 2a), b) $89.8 \%$, (Figure 2b), c) $85.7 \%$, (Figure 2c).

Computation of $S v k$ and $S p k$ parameters is performed from the height of the perpendicular triangles represented on the diagram (with an orange color): a) $S v k=0.0972 \mu \mathrm{m}$ and $S p k=0.128 \mu \mathrm{m}$; b) $S v k=0.0549 \mu \mathrm{m}$ and $S p k=0.0929 \mu \mathrm{m}$; c) $S v k=0.0982 \mu \mathrm{m}$ and $S p k=0.104 \mu \mathrm{m}$.

From the category of the functional parameters for the

\section{AFM analiza}

S pomoću mikroskopa atomskih sila (AFM-a) dobiveni su mikrografi uzoraka $(100 \mu \mathrm{m} \times 100 \mu \mathrm{m})$ pri istoj temperaturi, istoj vlažnosti zraka u kontaktnom načinu rada multimodalnoga AFM-a i Nanoscope III a controllera. Područja interesa na površini legure (ROI-s) identificirana su optičkom kamerom (Sony high resolution CCD camera, Japan). Detaljan opis AFM mjerenja može se naći u prijašnjim istraživanjima (18 - 20).

\section{Statistički opis 3D površinske hrapavosti}

MountainsMap ${ }^{\oplus}$ Premium software verzija 7 primijenjena je za dobivanje podataka o 3D površinskoj mikroteksturi (32). Ti parametri opisani su u protokolu ISO 25178 - 2: 2012. (33).

Izračun Minkowskijeve funkcije (MF-s) (volumen $V$, površina $S$ i Euler-Poincaréove karakteristike (ili broj konektiviteta $\chi$ )) obavljen je s pomoću softvera Gwyddion 2,37 (34). Softver se temelji na sljedećim matematičkim formulama:

$V=N_{\text {white }} / N ; S=N_{\text {bound }} / N ; \chi=\left(C_{\text {white }}-C_{\text {black }}\right) / N$

pri čemu je: $N$ ukupan broj piksela; $N_{\text {white }}$ označuje broj 'bijelih' piksela, što su zapravo pikseli iznad praga; $N_{\text {bound }}$ označava broj bijelo-crnih granica piksela; $C_{\text {white }}$ i $C_{\text {black }}$ brojevi su kontinuiranih setova bijelih i crnih piksela.

\section{Statistička analiza}

Za statističku analizu korišten je statistički paket za društvene znanosti (SPSS, verzija 20, Illinois, SAD). Kvantitativne varijable između različitih skupina uspoređivane su jednosmjernom analizom varijance (ANOVA-om) i post-hoc Schefféovim testom. Razina značajnosti bila je $\mathrm{p}<0,05$.

\section{Rezultati}

Relevantne dvodimenzijske AFM snimke uzoraka površine $100 \times 100 \mu \mathrm{m}^{2}$ prikazane su na slici 1 . za sve tri skupine uzoraka.

$\mathrm{Na}$ slici 2. je skup Sk parametara. Parametar Sk daje informacije o dubini jezgre i može se odrediti linijom koja presijeca os X na $0 \%$ i $100 \%$. Na grafičkom prikazu nacrtane su dvije linije paralelne $s$ osi $\mathrm{X}$, a izračunate vrijednosti parametra $S k$ za svaku skupinu su: a) $S k=0,17 \mu m$; b) $S k=0,201$ $\mu \mathrm{m}$; ) $S \mathrm{k}=0,183 \mu \mathrm{m}$.

Da bi se grafički odredile vrijednosti parametara Smr1 i Smr2, crtaju se paralelne linije $s$ osi Y koje će se presijecati paralelnim linijama s $\mathrm{X}$ osi koje su prije toga nacrtane u proračunu parametra Sk. Izračunate vrijednosti parametra Smr1 su: a) 13,8\%, (slika 2. a), b) 11,8\%, (slika 2. b); c) 11,7 \%, (slika 2. c), a vrijednosti za $S \mathrm{mr} 2$ parametar iznose: a) 88,6 \%, (slika 2. a), b) 89,8\%, (slika 2. b), c) 85,7\%, (slika 2. c). Izračunavanje Svk i Spk parametara obavlja se $s$ vrha okomitih trokuta prikazanih na dijagramu (narančastom bojom): a) Svk $=0,097 \mu \mathrm{m}$ i Spk $=0,128 \mu \mathrm{m}$; b) Svk = 0,049 $\mu \mathrm{m}$ i Spk = $0,0299 \mu \mathrm{m}$; c) Svk $=0,082 \mu \mathrm{m}$ i Spk $=0,104 \mu \mathrm{m}$.

Iz kategorije funkcionalnih parametara za volumen izračunati su Vmp, Vmc, Vvci, Vvv (slika 3.), uzimajući u obzir analognu metodu izračuna, a izračunati su i podatci dobiveni u krivulji omjera površine materijala. 

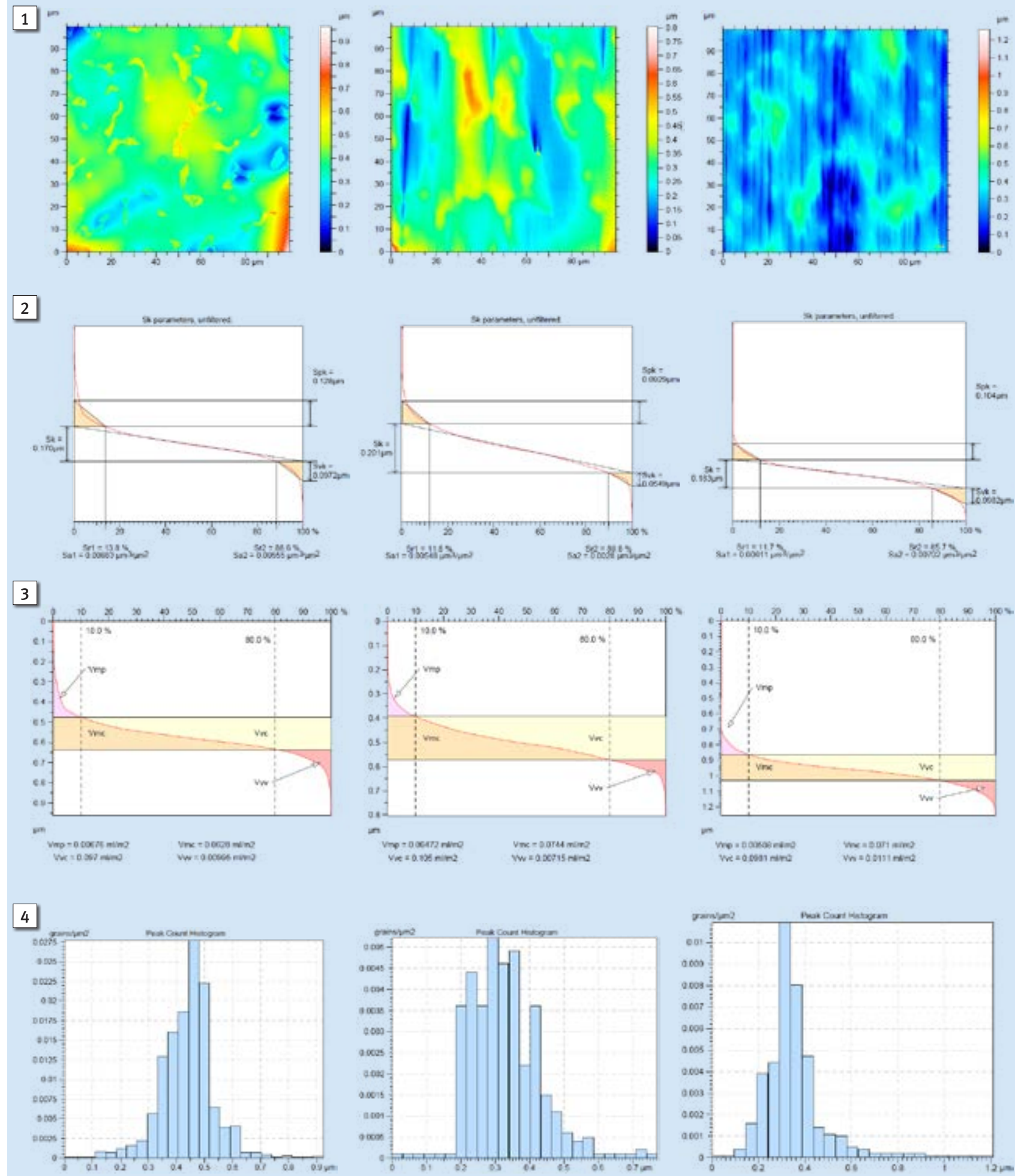

Figure 1 The relevant 2-D topographic AFM micrographs, for a $100 \times 100-\mu \mathrm{m}^{2} \mathrm{Co}-\mathrm{Cr}$-Mo dental alloy surface scanning square area: a) EP sample; b) RP sample; c) RPDL sample.

Slika. 1. Relevantni 2D topografski AFM mikrogrami za skenirane površine veličine 100 x 100- $\mu \mathrm{m}^{2}$ Co-Cr-Mo legure: a) EP uzorak; b) RP uzorak; c) RPDL uzorak

Figure 2 Areal material ratio curve with parameters: Sk, Spk, Svk, Smr1 and Smr2 for each group of the Co-Cr-Mo dental alloy: a) EP sample; b) RP sample; c) RPDL sample.

Slika 2. Krivulja omjera površine materijala s parametrima Sk, Spk, Svk, Smr1 i Smr2 za svaku skupinu Co-Cr-Mo legure: a) EP uzorak; b) RP uzorak; c) RPDL uzorak

Figure 3 Areal material ratio curve with parameters: $V m p, V m c, V v c$ and $V v v$ for each group of the Co-Cr-Mo dental alloy: a) EP sample; b) RP sample; c) RPDL sample.

Slika 3. Krivulja omjera površine materijala s parametrima Vmp, Vmc, Vvc i Vvv za svaku ispitivanu skupinu Co-Cr-Mo legure: a) EP uzorak; b) RP uzorak; c) RPDL uzorak

Figure 4 The peak count histograms for each group of the Co-Cr-Mo dental alloy: a) EP sample; b) RP sample; c) RPDL sample

Slika 4. Histogrami za svaku skupinu Co-Cr-Mo legure: a) EP uzorak, b) RP uzorak, c) RPDL uzorak 
5

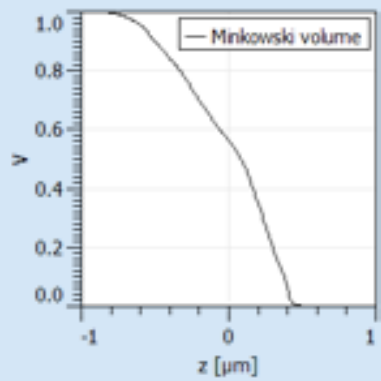

6

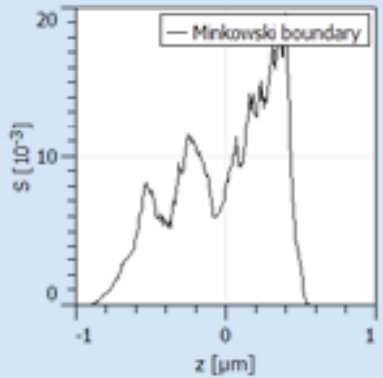

7

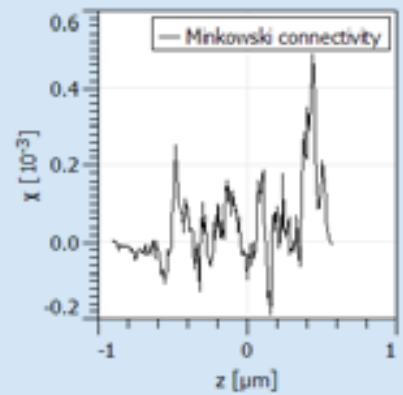

8

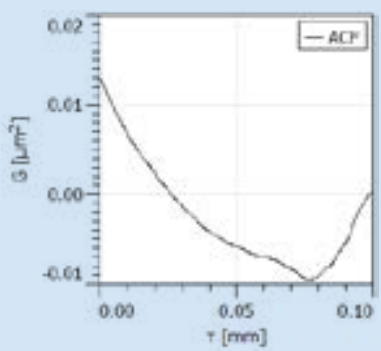

9

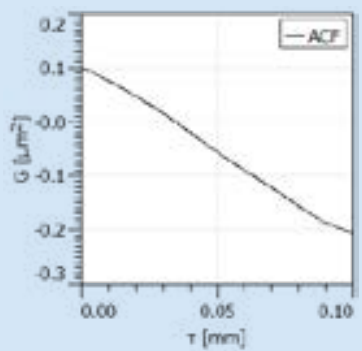

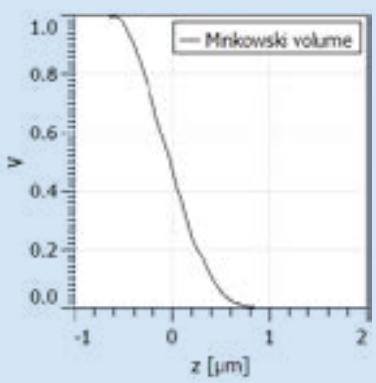
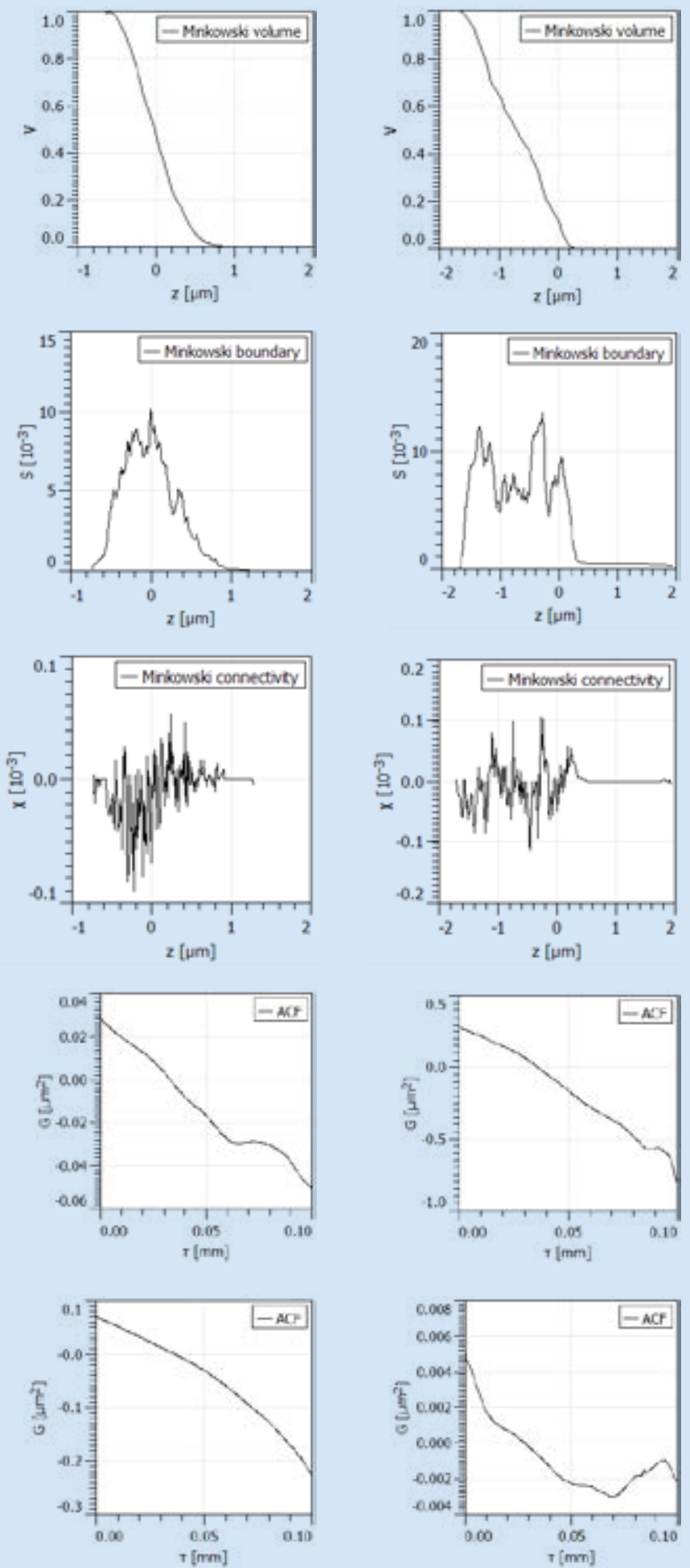

Figure 5 The Minkowski volume $V(z)$ [no unit] for each group of the Co-Cr-Mo dental alloy: a) EP sample; b) RP sample; $c$ ) RPDL sample.

Slika 5. Minkowskijev volumen V(z) [broj jedinica] za svaku skupinu Co-Cr-Mo legure: a) EP uzorak, b) RP uzorak, c) RPDL uzorak

Figure 6 The Minkowski surface S(z) [no unit] for each group of the Co-Cr-Mo dental alloy: a) EP sample; b) RP sample; c) RPDL sample.

Slika 6. Minkowskijeva površina: S(z) [broj jedinica] za svaku skupinu Co-Cr-Mo legure: a) EP uzorak, b) RP uzorak, c) RPDL uzorak

Figure 7 The Minkowski connectivity $X(z)$ [no unit] for each group of the Co-Cr-Mo dental alloy: a) EP sample; b) RP sample; c) RPDL sample.

Sika 7. Minkowskijeva povezivost X(z) [broj jedinica] za svaku skupinu Co-Cr-Mo legure: a) EP uzorak, b) RP uzorak, c) RPDL uzorak

Figure 8 The autocorrelation function (ACF), based on the linear interpolation type, for each group of the Co-Cr-Mo dental alloy: a) EP sample; b) RP sample; c) RPDL sample in horizontal direction.

Slika 8. Funkcija autokorelacije (ACF-a) koja se temelji na linearnom interpolacijskom tipu, za svaku skupinu Co-Cr-Mo legure: a) EP uzorak, b) RP uzorak, c) RPDL uzorak - u horizontalnom smjeru

Figure 9 The autocorrelation function (ACF), based on the linear interpolation type, for each group of the Co-Cr-Mo dental alloy: a) EP sample; b) RP sample; c) RPDL sample in vertical direction.

Slika 9. Funkcija autokorelacije (ACF-a) koja se temelji na linearnom interpolacijskom tipu, za svaku skupinu Co-Cr-Mo legure: a) EP uzorak, b) RP uzorak, c) RPDL uzorak - u vertikalom smjeru 
volume are calculated Vmp, Vmc, Vvci, Vvv (Fig. 3), considering an analogous calculation method, as well as the data obtained in the area material ratio curve. The calculation method takes into account the value of the parameters $m r 1(10 \%)$ and $m r 2(80 \%)$. The following values were obtained for peak material volume $(V m p):$ a) $0.00676 \mathrm{ml} / \mathrm{m}^{2}$, b) $0.00472 \mathrm{ml} /$ $\mathrm{m}^{2}$, c) $0.00508 \mathrm{ml} / \mathrm{m}^{2}$, as well as for the core material volume $(V m c):$ a) $V m c=0.0628 \mathrm{ml} / \mathrm{m}^{2}$, b) $V m c=0.0744 \mathrm{ml} /$ $\mathrm{m}^{2}$, c) $V m c=0.071 \mathrm{ml} / \mathrm{m}^{2}$. For dale void volume $(V v v)$ were obtained the following values: a) $0.00995 \mathrm{ml} / \mathrm{m}^{2}$, b) 0.00715 $\mathrm{ml} / \mathrm{m}^{2}$, c) $0.0111 \mathrm{ml} / \mathrm{m}^{2}$, while for core void volume $(V v c)$ these are: a) $0.097 \mathrm{ml} / \mathrm{m}^{2}$, b) $0.105 \mathrm{ml} / \mathrm{m}^{2}$, c) $0.0981 \mathrm{ml} / \mathrm{m}^{2}$.

The peak count histograms from Figure 4, a-c were computed according Ref. (32).

The computed MFs functions $V(z), S(z)$, and $X(\mathrm{z})$ are shown in Figs 5-7.

In Figures 8 and 9, the autocorrelation function (ACF), computed with a model of linear interpolation type: a) in a horizontal direction; b) in a vertical direction, are graphically represented.

\section{Discussion}

In the biomedical field, in the last few decades, a series of metal alloys have been successfully used as biomaterials. Chemical composition of both, cast and selective laser melting manufactured alloys are standardized, however, the microstructure of an alloy can vary in a size of its grains and phase types. In casted alloys, the microstructure depends on the process of manufacturing, heat treatment, cooling and final finishing (polishing). Therefore, we aimed to find out whether the surface of cast Co-Cr-Mo alloy varies dependent on certain polishing procedures which are the most frequently performed in dental laboratories because the difference in a surface microtexture may influence the alloy's corrosion behavior.

Some researchers $(14,15)$ reported that cast Co-Cr-Mo alloys have dendritic microstructured surface with 1 to $4-\mathrm{nm}$ thick stable oxide layer that constitutes a biological corrosion barrier opposing oral environment (35). Additionally, 20 to $40-\mu \mathrm{m}$ long and 150 to $400-\mu \mathrm{m}$ high undulations of the smooth surface have been reported (20).

An undulating pattern can be observed on the EP samples with islands of crystallites emerging from the surface with a typical saw-tooth pattern on the top (Figure 1a).

The surface microtexture of a RP sample is shown in Figure $1 \mathrm{~b}$ where "islands" preserve the contour (perimeter) similarly to EP samples, but the peaks of crystallites are smoothed (removed), as a result of additional polishing. Crystallites forming islands have been smoothed and polished to the height of $40 \mathrm{~nm}$. As a result of the action of a rotary brush, on the AFM microphotographs, one can observe parallel scratches drawn and on the undulating surface of the specimens. These scratches are V-profile 13-26 $\mu \mathrm{m}$ apart from each other. Their surface openings measure approximately $0.5-2 \mu \mathrm{m}$ in width and are $15-100 \mathrm{~nm}$ deep.

The RPDL sample surface microtexture is shown in Figure 1c. On these samples, the undulating surface has more scratches than RP samples; the distances between scratches are smaller (denser scratches). The undulated surface and is-
Metoda izračuna uzima u obzir vrijednosti parametara mr1 (10 \%) i mr2 (80 \%). Sljedeće vrijednosti dobivene su za vršni volumen materijala (Vmp): a) $0,00676 \mathrm{ml} / \mathrm{m}^{2}$, b) $0,00472 \mathrm{ml} / \mathrm{m}^{2}$, c) $0,00508 \mathrm{ml} / \mathrm{m}^{2}$ te za volumen jezgre materijala (Vmc): a) $\mathrm{Vmc}=0,0628 \mathrm{ml} / \mathrm{m}^{2}$, b) $\mathrm{Vmc}=0,0744$ $\left.\mathrm{ml} / \mathrm{m}^{2}, \mathrm{c}\right) \mathrm{Vmc}=0,071 \mathrm{ml} / \mathrm{m}^{2}$.

Za volumen dolina i praznina $(V v v)$ dobivene su sljedeće vrijednosti: a) $0,00995 \mathrm{ml} / \mathrm{m}^{2}$, b) $0,00715 \mathrm{ml} / \mathrm{m}^{2}$, c) $0,0111 \mathrm{ml} / \mathrm{m}^{2}$, a vrijednosti jezgre i praznina $(V v c)$ iznose: a) $0,097 \mathrm{ml} / \mathrm{m}^{2}$, b) $0,105 \mathrm{ml} / \mathrm{m}^{2}$, c) $0,0981 \mathrm{ml} / \mathrm{m}^{2}$.

Histogrami slike 4, a - c izračunati su prema referenciji (32).

Izračunate MF-s funkcije V (z), S (z) i X (z) prikazane su na slikama od 5. do 7.

$\mathrm{Na}$ slikama 8. i 9. grafički su prikazane funkcije autokorelacije (ACF-a) izračunate modelom linearnog interpolacijskog tipa: a) u horizontalnom smjeru; b) u vertikalnom smjeru.

\section{Rasprava}

U posljednjih nekoliko desetljeća niz metalnih legura uspješno se upotrebljava kao biomaterijal u području biomedicine. Kemijski sastav legura za lijevanje i selektivno lasersko taljenje je standardiziran, no mikrostruktura legure može varirati u veličini zrna i vrstama faza. Mikrostruktura u lijevanim legurama ovisi o procesu proizvodnje, toplinskoj obradi, hlađenju i završnoj obradi površine (poliranju). Zato smo željeli istražiti postolje li razlike na površini lijevane $\mathrm{Co}-\mathrm{Cr}-\mathrm{Mo}$ legure, ovisno o određenim postupcima poliranja koji se najčešće primjenjuju u zubnim laboratorijima jer razlika u površinskoj mikroteksturi može utjecati na korozijsko ponašanje legure. Neki istraživači $(14,15)$ istaknuli su da izlivene CoCr-Mo legure imaju dendritičnu mikrostrukturiranu površinu sa stabilnim slojem oksida debljine od 1 do 4 nm koji je biološka barijera koroziji u intraoralnom okružju (35). Nadalje, zabilježene su undulacije glatke površine duge od 20 do $40 \mu \mathrm{m}$, a visoke od 150 do $400 \mu \mathrm{m}$ (20).

Undulirajuća površina vidi se na EP uzorcima, a vide se i otočići kristalita koji izlaze iz površine u tipičnoj zupčastoj (nazubljenoj) formaciji na vrhu (slika 1.a).

Mikrotekstura površine RP uzoraka na slici 1. b pokazuje da su otočići sačuvali konturu (perimetar) slično kao i EP uzorci, ali su vrhovi kristalita zaobljeni (uklonjeni), što je rezultat dodatnog poliranja. Kristaliti koji formiraju otoke izglađeni su i polirani do visine od $40 \mu \mathrm{m}$. Kao rezultat akcije rotirajuće četke, na AMF mikrogrmima mogu se vidjeti paralelne ogrebotine na undulirajućoj površini uzoraka. Te ogrebotine imaju V-profil i uzajamno su udaljene od 13 do $26 \mu \mathrm{m}$. Otvori ogrebotina široki su na površini otprilike 0,5 do $2 \mu \mathrm{m}$, a dubina im je od 15 do $100 \mathrm{~nm}$.

Površinska mikrostruktura RPDL uzoraka prikazana je na slici 1. c. Na tim uzorcima undulirajuća površina ima više ogrebotina od RP uzoraka i udaljenost između ogrebotina je manja (gušće ogrebotine). Undulirajuća površina, kao i otočići ispoliranih kristalita, poprečno su iskrižani mnogim paralelnim ogrebotinama. 
Table 1 The computed values of the statistical surface roughness parameters for each group: a) EP sample; b) RP sample; c) RPDL sample. Tablica 1. Izračunate vrijednosti parametara statističke hrapavosti površine za svaku skupinu: a) EP uzorak; b) RP uzorak; c) RPDL uzorak

\begin{tabular}{|c|c|c|c|c|c|}
\hline \multirow{2}{*}{ The statistical parameters } & \multirow{2}{*}{ Symbol } & EP sample & RP sample & RPDL sample & P values * \\
\hline & & Values & Values & Values & {$[-]$} \\
\hline Sk parameter & $S k[\mu \mathrm{m}]$ & 0.17 & 0.201 & 0.183 & 0.012 \\
\hline Smrl parameter & Smrl [\%] & 13.8 & 11.8 & 11.7 & 0.016 \\
\hline Smr2 parameter & Smr2 [\%] & 88.6 & 89.8 & 85.7 & 0.014 \\
\hline Svk parameter & $S v k[\mu \mathrm{m}]$ & 0.0972 & 0.0549 & 0.0982 & 0.027 \\
\hline$S p k$ parameter & $S p k[\mu \mathrm{m}]$ & 0.128 & 0.0929 & 0.104 & 0.025 \\
\hline Peak material volume & $V m p\left[\mathrm{ml} / \mathrm{m}^{2}\right]$ & 0.00676 & 0.00472 & 0.00508 & 0.021 \\
\hline Core material volume & $V m c\left[\mathrm{ml} / \mathrm{m}^{2}\right]$ & 0.0628 & 0.0744 & 0.071 & 0.028 \\
\hline Dale void volume & $V v v\left[\mathrm{ml} / \mathrm{m}^{2}\right]$ & 0.00995 & 0.00715 & 0.0111 & 0.029 \\
\hline Core void volume & $V v c\left[\mathrm{ml} / \mathrm{m}^{2}\right]$ & 0.097 & 0.105 & 0.0981 & 0.018 \\
\hline Arithmetic mean height & $S a[\mu \mathrm{m}]$ & 0.0662 & 0.0638 & 0.0643 & 0.019 \\
\hline Root mean square height & $S q[\mu \mathrm{m}]$ & 0.086 & 0.0816 & 0.0847 & 0.022 \\
\hline
\end{tabular}

* Statistically significant difference for all values: $P<0.05$.

lands of smoothed crystallites are crossed by many parallel scratches.

Computed values of the statistical surface roughness parameters, in accordance with ISO 25178-2: 2012 (33) are shown in Table 1.

The smallest arithmetic mean height $S a(0.0638 \mu \mathrm{m})$ was obtained from the RP samples, while the highest value $(0.0662 \mu \mathrm{m})$ was obtained on the EP samples. The mean height $S a$ of $0.0643 \mu \mathrm{m}$ was observed for PRDL samples. Similar ordering was found for the root mean square height $S q$ parameter.

The highest values of: Sq, Sa, Vm, Vmp were recorded on the EP specimens. The RPDL specimens had higher values of Sq, Sa, Vm, Vmp, and Vvv than the RP samples. The RP specimens had the smallest values, respectively.

Topographical results obtained from AFM are confirmed by the Minkowski functionals (MFs) and the autocorrelation functions (ACF) in horizontal and vertical direction.

After the EP procedure, mechanical polishing changed the morphology of the islands of crystallites emerging vertically from the undulating surface. As the crystallite peaks of islands of EP samples were smoothed by additional mechanical procedures, surface roughness generally decreased. However, the scratches formed by further polishing procedure were mostly parallel to each other. The surfaces of islands became almost featureless (without any peaks) and were smooth on the top. The RPDL samples appeared to have more scratches than the RP samples; the depths of RPDL scratches were up to $100 \mathrm{~nm}$, thus increasing surface roughness; therefore, the smoothening of islands did not cause a significant decrease of overall surface roughness (Figure $1 \mathrm{~b}$ and Figure 1c). However, deeper scratches, formed by mechanical polishing and consequent crystal grain deformation in the RPDL samples may lead to intergranular corrosion and crystallographic etching in intraoral aggressive environment.

The obtained results of this research are in line with studies $(18,20)$, which demonstrated that the surface microtexture can be correlated with the composition of dental materials and the corresponding protocols of surface polishing.
Izračunate vrijednosti statističkih parametara hrapavosti površine prema protokolu ISO 25178-2: 2012 (33) nalaze se u tablici 1 .

Najmanja aritmetička srednja vrijednost visine $S a(0,0638$ $\mu \mathrm{m})$ bila je na RP uzorcima, a najveća srednja vrijednost visine $(0,0662 \mu \mathrm{m})$ zabilježena je na EP uzorcima. Srednja visina $S a$ veličine od $0,0643 \mu \mathrm{m}$ zabilježena je na PRDL uzorcima. Sličan redoslijed zabilježen je i za parametar korijena aritmetičkih sredina kvadrata visina: $S q$.

Najviše vrijednosti parametara Sq, Sa, Vm, Vmp, zabilježene su na EP uzorcima. RPDL uzorci imali su veće vrijednosti parametara Sq, Sa, Vm, Vmp i Vvv negoli RP uzorci. RP uzorci imali su najniže vrijednosti tih parametara.

Topografski rezultati dobiveni AFM-om potvrđeni su Minkowskijevim funkcijama (MFs) i autokorelacijskim funkcijama (ACF-om) i u horizontalnom i u vertikalnom smjeru.

$\mathrm{Na}$ EP uzorcima je dodatno mehaničko poliranje promijenilo morfologiju otočića kristalita koji su se vertikalno izdizali iz undulirajuće površine. Njihovi vrhovi izglađeni su dodatnim mehaničkim postupcima poliranja, a hrapavost površine općenito se smanjila. No ogrebotine nastale dodatnim poliranjem rotirajućom četkom bile su najčešće paralelne. Površina otočića postala je gotovo bezlična (bez vrhova) i glatko zaobljena odozgo. RPDL uzorci imali su više ogrebotina od RP uzoraka; dubina ogrebotina na RPDL uzorcima bila je do $100 \mathrm{~nm}$ pa su povećavale hrapavost površine; zato izglađeni otočići nisu pridonijeli i općem smanjenju hrapavosti površine (slike 1. b i 1. c). Dublje ogrebotine, nastale mehaničkim poliranjem i posljedičnom deformacijom kristalnih zrna u RPDL uzorcima, mogu uzrokovati intergranularnu koroziju i kristalografsko nagrizanje u slučaju agresivnog okoliša unutar usne šupljine.

Rezultati ovog istraživanja u skladu su s nekim drugim istraživanjima $(18,20)$ koja su pokazala da se tekstura površine može korelirati sa sastavom materijala i odgovarajućim protokolima poliranja površine. 


\section{Conclusion}

This study suggests that in the case of final surface finishing procedures, the specific micromorphology parameters of the surface microtexture on different surfaces of Co-Cr-Mo alloy are influenced by the polishing effects. These statistical surface roughness parameters are important in designing and manufacturing materials with optimal texture surfaces.

\section{Acknowledgments}

We are grateful to Assoc. Prof. Sonia Munteanu, PhD., The Modern Languages and Communication Department from the Technical University of Cluj-Napoca, for her linguistic contribution to this paper.

\section{Appendix}

The definitions of main statistical parameters applied in 3-D surface roughness analyses (height parameters, functional parameters and functional volume parameters), defined in accordance with ISO 25178-2: 2012 (33) are presented in Figure 10.

\section{Conflict of interest}

None declared.

\section{Zaključak}

Ovo istraživanje upozorava na to da na specifične mikromorfometrijske parametre mikroteksture površine pri završnoj obradi površine $\mathrm{Co}-\mathrm{Cr}-\mathrm{Mo}$ legure utječe način poliranja. Ti statistički parametri površinske hrapavosti važni su u dizajniranju i proizvodnji materijala optimalne površinske teksture.

\section{Zahvale}

Zahvaljujemo prof. dr. sc. Sonia Munteanu iz Zavoda za suvremene jezike i komunikaciju s Tehničkoga fakulteta Cluj-Napoca za doprinos verziji ovog rada na engleskome jeziku.

\section{Privitak}

Definicija najvažnijih statističkih parametara koji su primijenjeni u 3D analizi hrapavosti površine (parametri visine, funkcionalni parametri i funkcionalni parametri volumena) definirani prema protokolu ISO 25178-2: 2012 (33) prikazani su na slici 10 .

\section{Sukob interesa}

Autori nisu bili u sukobu interesa.

\footnotetext{
$\operatorname{Vm}(\mathrm{p})$ - Material volume is the volume of the material at a material ratio $\mathrm{p}$ (in \%). In our study, $\mathrm{p}=10 \%$. Volumen materijala je obujam materijala u omjeru $\mathrm{p}(\mathrm{u} \%)$, što $\mathrm{u}$ ovom istraživanju iznosi $\mathrm{p}=10 \%$.

$\mathrm{Vv}(\mathrm{p})$ - Void volume is the volume of the voids at a material ratio $\mathrm{p}$ (in \%). In our study, $\mathrm{p}=10 \%$. Volumen praznine je volumen praznina u omjeru $\mathrm{p}(\mathrm{u} \%)$; $\mathrm{u}$ ovom istraživanju $\mathrm{p}=10 \%$.

Vmp - Peak material volume of the scale limited surface is the volume of material in the peaks, bettween $0 \%$ material ratio and a material ratio p (in $\%$ ), calculated in the zone above $\mathrm{cl}, \mathrm{Vmp}=\mathrm{Vm}(\mathrm{p})$. In our study, $\mathrm{p}=10 \%$. Najveći volumen materijala na skali ograničene površine je volumen materijala u vršnim vrijednostima, između $0 \%$ i omjera $\mathrm{p}(\mathrm{u} \%)$, izračunato iz zone iznad $\mathrm{cl}$. Vmp $=\mathrm{Vm}(\mathrm{p})$; u ovom istraživanju $\mathrm{p}=10 \%$.

Vmc - Core material volume of the scale limited surface is the volume of material in the core or kernel, between two material ratios p and $q$ (in \%), calculated in the zone between $\mathrm{c} 1$ and $\mathrm{c} 2 . \mathrm{Vmc}=\mathrm{Vm}(\mathrm{q})-\mathrm{Vm}(\mathrm{p})$. In our study, $\mathrm{p}=10 \%, \mathrm{q}=80 \%$. Volumen jezgre materijala na ljestvici ograničene površine je volumen materijala $\mathrm{u}$ jezgri ili zrnu, izveđu 2 omjera p i q (u \%), što je izračunato iz zone $\mathrm{c} 1$ i c2. $\mathrm{Vmc}=\mathrm{Vm}(\mathrm{q})-\mathrm{Vm}(\mathrm{p})$; u ovom istraživanju $\mathrm{p}=10 \%, \mathrm{q}=80 \%$.

Vvc - Core void volume of the scale limited surface is the volume of void in the core or kernel, between two material ratios p and $q$ (in $\%$ ), calculated in the zone between $\mathrm{c} 1$ and $\mathrm{c} 2 . \mathrm{Vvc}_{\mathrm{vc}}=\mathrm{Vv}(\mathrm{p})-\mathrm{Vv}_{\mathrm{v}}(\mathrm{q})$. In our study, $\mathrm{p}=10 \%, \mathrm{q}=80 \%$. $\bullet$ Volumen praznine jezgre ograničene površine je volumen praznina $\mathrm{u}$ jezgri ili zrnu, između 2 omjera p i q (u \%), izračunat iz zone između c1 i c2. $V_{v c}=V_{v}(p)-V_{v}(q)$; u ovom istraživanju p $=10 \%, q=80 \%$.

Vvv - Pit void volume of the scale limited surface is the volume of void in the valleys, between a material ratio p (in \%) and $100 \%$ material ratio, calculated in the zone below c2. $\mathrm{Vvv}=\mathrm{Vv}(\mathrm{p})$. In our study, $\mathrm{p}=80 \%$. $\bullet$ Volumen praznine udubina ograničene površine je volumen udubina u udolinama između omjera materijala $\mathrm{p}$ (u $\%)$ i $100 \%$, što je izračunato iz zone ispod c2, $\mathrm{Vvv}=\mathrm{Vv}(\mathrm{p})$; u ovom istraživanju, $\mathrm{P}=80 \%$.

(Sa) - Arithmetical mean height is the mean surface roughness. • Aritmetička sredina visine, srednja hrapavost.

(Sq) - Root mean square height is the standard deviation of the height distribution, or RMS surface roughness. Korijen iz aritmetičkih sredina kvadrata visina je standardna devijacija distribucije visine ili RMS hrapavost površine.
}

Figure 10 The definitions of main statistical parameters applied in 3-D surface roughness analyses. Slika 10. Definicija najvažnijih statističkih parametara primijenjenih u 3D analizi površine

\section{Sažetak}

Svrha: Kvantificiran je utjecaj triju različitih postupaka završne obrade površine kobalt-krom-molibdenovom (Co-Cr-Mo) legurom s pomoću parametara stereometrijske analize. Materijal i metode: Izliveno je 18 uzoraka ekstra tvrde legure (Wironit ${ }^{\circledR}$, BEGO, Bremen, Njemačka). Uzorci su podijeljeni u tri skupine ( $n=6$ uzoraka u svakoj), ovisno o primijenjenoj tehnici poliranja i to kako slijedi: A skupina - samo elektropolirani uzorci (EP); B skupina - nakon EP-a površina je dodatno mehanički polirana gumenim diskovima, pastom za poliranje i rotirajućom četkom (RP); C skupina - nakon EP-a, završno mehaničko poliranje obavljeno je gumenim diskovima, pastom za poliranje i rotirajućim kolutom od jelenje kože (RPDL). Svi uzorci analizirani su mikroskopom atomskih sila (AFM-om) u kontaktnom načinu rada, na zraku i pri sobnoj temperaturi. Rezultati: Procjena mikroteksture površine uzoraka učinjena s pomoću 3D parametara za procjenu hrapavosti. Najniži parametri površine nađeni su u RP skupini, a najviši u EP skupini. Zaključci: Opisani eksperimenti mogu koristiti proizvođačima da identificiraju najpovoljnije parametre i njihove raspone za postizanje optimalnih svojstava površine.
Zaprimljen: 31. listopada 2018. Prihvaćen: u travnju 2019.

Adresa za dopisivanje Prof. Asja Čelebić Sveučilište u Zagrebu Stomatološki fakultet Zavod za mobilnu protetiku Gundulićeva 5, 10000 Zagreb, Hrvatska celebic@sfzg.hr

Ključne riječi stomatološko poliranje; stomatološke legure; kobalt; krom; molibden; površinska svojstva 


\section{References}

1. Dănăilă E., Bounegru I., Benea L., Chiriac A. Improving biocompatibility of $\mathrm{Co}-\mathrm{Cr}$ alloy used in dentistry by surface modification with electrochemical methods - corrosion of untreated $\mathrm{Co}-\mathrm{Cr}$ alloy in solution with different $\mathrm{pH}$. The Annals of "Dunărea de Jos" University of Galați, Fascicle IX, Metallurgy and Materials Science. 2014;2:54-59.

2. Kim H.R., Jang S.H., Kim Y.K., Son J.S., Min B.K., Kim K.H., Kwon T.Y. Microstructures and mechanical properties of Co-Cr dental alloys fabricated by three CAD/CAM-based processing techniques. Materials (Basel). 2016;9(7):596. DOI: 10.3390/ma9070596.

3. Sonofuchi K., Hagiwara Y., Koizumi Y., Chiba A., Kawano M., Nakayama M., Ogasawara K., Yabe Y., Itoi E. Quantitative in vivo biocompatibility of new ultralow-nickel cobalt-chromium-molybdenum alloys. J Orthop Res. 2016;34(9):1505-13. DOI: 10.1002/ jor.23150.

4. Antanasova M., Kocjan A., Kovač J., Žužek B., Jevnikar P. Influence of thermo-mechanical cycling on porcelain bonding to cobalt-chromium and titanium dental alloys fabricated by casting, milling, and selective laser melting. J Prosthodont Res. 2018;62(2):184-194. DOI: 10.1016/j.jpor.2017.08.007.

5. Park W.U., Park H.G., Hwang K.H., Zhao J., Lee J.K. Interfacial property of dental Cobalt-Chromium alloys and their bonding strength with porcelains. J Nanosci Nanotechnol. 2017;17(4):2585-588.

6. Al Jabbari Y.S. Physico-mechanical properties and prosthodontic applications of $\mathrm{Co}-\mathrm{Cr}$ dental alloys: a review of the literature. J Adv Prosthodont. 2014;6(2):138-45. DOI: 10.4047/jap.2014.6.2.138.

7. Hooper P.A. Melt pool temperature and cooling rates in laser powder bed fusion. Adv. Manuf. Technol. 2018;22:548-559.

8. Gough J.E., Clupper D.C., Hench L.L. Osteoblast responses to tape-cast and sintered bioactive glass ceramics. J Biomed Mater Res A. 2004;69(4):621-628.

9. Quirynen M., Bollen C.M. The influence of surface roughness and surface-free energy on supra-and subgingival plaque formation in man: a review of the literature. I Clin Periodontol. 1995;22(1):1-14

10. Bollen C.M., Lambrechts P., Quirynen M. Comparison of surface roughness of oral hard materials to the threshold surface roughness for bacterial plaque retention: a review of the literature. Dent Mater. 1997;13(4):258-269.

11. Grössner-Schreiber B., Griepentrog M., Haustein I., Müller W.D., Lange K.P., Briedigkeit H., Göbel U.B. Plaque formation on surface modified dental implants. An in vitro study. Clin Oral Implants Res. 2001;12(6):543-551.

12. Tanner J., Carlen A., Soderling E., Vallittu P.K. Adsorption of parotid saliva proteins and adhesion of Streptococcus mutans ATCC 21752 to dental fiber-reinforced composites. J Biomed Mater Res A Appl Biomater. 2003;66(1):391-398.

13. Aydin A.K. Evaluation of finishing and polishing techniques on surface roughness of chromium-cobalt castings. J Prosthet Dent. 1991;65(6):763-767

14. Matkovic T., Matkovic P., Malina J. Effects of Ni and Mo on the microstructure and some other properties of Co-Cr dental alloys. J Alloy Compd. 2004;366(1-2):293-297.

15. Matkovic T., Slokar Lj., Matkovic P. Structure and properties of biomedical Co-Cr-Ti alloys. J Alloy Compd. 2006;407(1-2):294-298

16. Tălu S. Micro and nanoscale characterization of three dimensional surfaces. Basics and applications. Napoca Star Publishing House: Cluj-Napoca, Romania; 2015.

17. Bezzon O.L., Pedrazzi H., Zaniquelli O., da Silva T.B. Effect of casting technique on surface roughness and consequent mass loss after polishing of $\mathrm{NiCr}$ and $\mathrm{CoCr}$ base metal alloys: A comparative study with titanium. J Prosthet Dent. 2004;92(3):274-277.

18. Klaić B., Svetličić V., Čelebić A., Mišić T., Šegota S., Baučić I., Žutić V. Analysis of surface topography and surface roughnes of $\mathrm{CoCr}$ alloy samples by atomic force microscopy. Acta Stomatol Croat. 2007;41(4):306-314.
19. Tălu S., Stach S., Klaić B., Mišić T., Malina J., Čelebić A. Morphology of Co-Cr-Mo dental alloy surfaces polished by three different mechanical procedures. Microsc. Res. Tech. 2015;78:831-839. DOI: $10.1002 /$ jemt.22547.

20. Čelebić A., Svetličić V., Malina J., Klaić B. Co-Cr-Mo alloy surface features and composition prior and after mechanical polishing and corrosion in fluids simulating oral conditions. In: Biomaterials Developments and Applications, Bourg H., Lisle A. (eds.). New York: Nova Science Publishing, 2010, pp. 415-433.

21. Tălu Ş. Mathematical methods used in monofractal and multifractal analysis for the processing of biological and medical data and images. Anim Biol Anim Husb. 2012;4:1-4.

22. Tălu Ş. Texture analysis methods for the characterisation of biological and medical images. Extreme Life, Biospeology \& Astrobiology. 2012;4:8-12.

23. Berezina S., Il'icheva A.A., Podzorova L.I., Țălu Ş. Surface micromorphology of dental composites [CE-TZP] - $\left[\mathrm{AL}_{2} \mathrm{O}_{3}\right]$ with $\mathrm{Ca}^{+2}$ modifier. Microsc. Res. Tech. 2015;78:840-846. DOI: 10.1002/ jemt.22548.

24. Tălu Ş., Stach S., Alb S.F., Salerno M. Multifractal characterization of a dental restorative composite after air-polishing. Chaos, Solitons \& Fractals. 2015;71:7-13. DOI:10.1016/j.chaos.2014.11.009.

25. Salerno M., Giacomelli L., Derchi G., Patra N., Diaspro A. Atomic force microscopy in vitro study of surface roughness and fractal character of a dental restoration composite after air-polishing. BioMedical Engineering OnLine. 2010;9:59. DOI: 10.1186/1475925X-9-59.

26. Sobola D., Tălu Ş., Solaymani S., Grmela L., Influence of scanning rate on quality of AFM image: Study of surface statistical metrics. Microsc. Res. Tech. 2017;80(12):1328-1336. DOI: 10.1002/ jemt.22945.

27. Țălu Ş., Stach S., Lainović T., Vilotić M., Blažić L., Alb S.F., Kakaš D. Surface roughness and morphology of dental nanocomposites polished by four different procedures evaluated by a multifractal approach. Appl Surf Sci. 2015;330:20-29. DOI: 10.1016/j.apsusc.2014.12.120.

28. Țălu Ş., Patra N., Salerno M. Micromorphological characterization of polymer-oxide nanocomposite thin films by atomic force microscopy and fractal geometry analysis. Progress in Organic Coatings. 2015;89:50-56. DOI:10.1016/j.porgcoat.2015.07.024.

29. Moldovan M., Prodan D., Popescu V., Prejmerean C., Saroși C., Saplonțai M., Tălu Ş., Vasile E. Structural and morphological properties of HA-ZnO powders prepared for biomaterials. Open Chem. 2015;13:725-733. DOI: 10.1515/chem-2015-0083.

30. Sánchez I., Uzcátegui G. Fractals in dentistry. J Dent. 2011;39:273292.

31. Tălu Ş., Stach S., Lainović T., Blažić L. Characterization of spatial patterns of dental restorative nanocomposites. Microsc. Res. Tech. DOI: 10.1002/jemt.23270.

32. MountainsMap ${ }^{\circledR} 7$ Software (Digital Surf, Besançon, France). Available from: http://www.digitalsurf.fr (last accessed August $\left.30^{\text {th }}, 2019\right)$.

33. ISO 25178-2: 2012, Geometrical product specifications (GPS) - Surface texture: Areal - Part 2: Terms, definitions and surface texture parameters. Available from: http://www.iso.org (last accessed August $30^{\text {th }}, 2019$ ).

34. Gwyddion 2.37 software (Copyright Š 2004-2007, 2009-2014 Petr Klapetek, David Nečas, Christopher Anderson). Available from: http://gwyddion.net (last accessed August 30 ${ }^{\text {th }}, 2019$ ).

35. Milosev I., Strehblow H.H. The composition of the surface passive film formed on CoCrMo alloy in simulated physiological solution. Electrochimica Acta. 2003;48(19):2767-2774. 